\title{
Comparison and Understanding of a Third Grade Class Schedule in Rural Primary Schools in China and the Czech Republic
}

\section{Wanbin She, Qianjun Tang}

\begin{abstract}
Through a case comparison of the third grade schedule Chinese and Czech rural primary schools, it was found that there is a significant gap between compulsory education in China compared to the Czech Republic in terms of school work, pupils' free time, extracurricular activities, the rationality of scheduling or timetabling arrangements, inclusive education, etc. This suggests that schooling should start with fewer courses and lessons to reduce the academic burden; cultivate morality education from daily activities; ability training could reform university education resource utilization, and improve the convenience of education service; it should actively expand the autonomy of places and schools to improve quality; inclusive education should be implemented to ensure the rights of children with special educational needs.
\end{abstract}

Keywords: basic education, rural school in China and Czech Republic, class schedule, comparison and revelation. 


\title{
Srovnání rozvrhu třetí třídy na venkovských základních školách v Číně a České republice
}

\begin{abstract}
Abstrakt
Prostřednictvím případové studie třetích tříd čínských a českých venkovských základních škol bylo zjištěno, že ve srovnání s Českou republikou existují v čínských školách značné rozdíly, pokud jde o školní práci, volný čas a mimoškolní aktivity žáků, racionální rozvrh včetně inkluzivního vzdělávání atd. Výzkum naznačuje, že bychom snížit počet vyučovacích hodin a akademickou zátěž; kultivovat morální výchovu vycházející z každodenních činností; trénink schopností by měl reformovat využívání zdrojů vysokoškolského vzdělávání a zlepšovat úroveň komfortu vzdělávacích služeb; měla by se aktivně rozšiřovat autonomie a kvalita zlepšovat podniků a škol, mělo by být zavedeno inkluzivní vzdělávání k zajištění práv dětí se speciálními vzdělávacími potřebami.
\end{abstract}

Klíčová slova: základní vzdělání, venkovská škola v Číně a České republice, rozvrh, srovnání a zjištění.

DOI: $10.5507 /$ epd.2019.027

\section{Introduction}

The Czech Republic is a landlocked country in central Europe with a strong European culture. As the inventor of the class teaching system and the birthplace of Comenius, the founder of modern Western education theory, Czech education has a long history. In 2007, the Czech Republic launched basic education reform, comprehensively reforming the education system, education content and teaching methods used for decades (OECD, 2013). Although the reform was controversial at the beginning, after ten years of implementation and development, Czech basic education has achieved an overall improvement (Krstić K., et al., 2017). In 2015, the author visited the Pedagogical Faculty of Palacky University in Czech Republic for a short period and was particularly impressed by the basic education in the Czech Republic. This paper intends to provide a new perspective and draw inspiration for basic education reform in China by comparing and analysing the third-grade curriculum schedules of two rural primary schools: one in the Czech Republic and one in China.

Curriculum scheduling or timetabling, as the main external manifestation of curriculum planning, is a way for teachers to implement courses in a planned way and the tool to promote students' planned learning (Ping Zh., Huang Decheng, 1989). The 
rationality of school curriculum arrangements affects students' learning efficiency and teachers' teaching quality.

Different scholars have different definitions of the content of the curriculum. For example, Rowntree argues that a timetable is a detailed list for each teacher in each class or an overall educational organization (Rowntree, D., 1981). According to Shinkai, the schedule represents the various educational activities arranged and the time allocation of teaching subjects on a weekly basis (Zhang Nianhong, 1987). Zhang Nianhong believes that the curriculum is the specific table of the school teaching programme (Zhang Nianhong, 1987). From the perspective of educational history, a curriculum timetable is the direct product of the division of teaching and the class teaching system. In the theoretical field, the arrangement of curriculum schedule is beneficial to teachers' teaching or students' learning (Zhang Liyong, 2008; Zhu Min, 2002; Ngajie, et al., 2016). Considering that students' growth is the direct goal of education, it is a basic consensus in academic circles to arrange the curriculum schedule in favour of students' learning and development in accordance with the regularity of students' learning and the value of curriculum functions. Due to the different educational systems, educational ideas, educational policies and training objectives in different countries, the curriculum layout and design is different (Glatthorn, 2003). For example, some scholars compared the curriculum schedules of Chinese and Australian middle schools and analyzed the differences in curriculum setting and class hour allocation between Chinese and Australian middle schools (2015). They found that Chinese courses are mainly divided into subjects, while Australian courses are combined with comprehensive courses. Chinese middle schools have intensive class hours, while Australian courses are relatively loose (2015).

\section{Methodology}

\subsection{The logic of sampling}

As is well-known, basic or elementary education is a fundamental part of public education around the world. To ensure quality and development levels the elementary schools of various levels must be in accordance with the requirements for the unified national standards and organize the implementation of these standards including setting targets. These include curriculum content and development, timetabling, and establishing clear rules. The curriculum schedule and allocation of time is the most direct and intuitive tool to reflect the goals, contents and requirements of basic education in each country. In 2007, the Czech Republic disseminated the Framework Educational Programme for Basic Education (FEP BE), which clearly stipulated the goals, fields, content, curriculum setting and time allocation of basic education for the whole 
country, and with this carried out a new round of basic education reform. In 2001, China promulgated the experimental plan of curriculum setting in compulsory education and undertook the reform experiment of compulsory education curriculum. It is more than ten years since the implementation of the two reform plans, therefore a comparison and analysis of the curriculum schedule of the third grade of a rural primary school in each country would be helpful to better examine the experimental schemes of basic education curriculum in China and reflect on another countries' experience for further deepening the reform of the plan.

\subsection{Sampling}

We chose the grade three schedule of a school in the Bohemia region of the northeast of the Czech Republic for the research sample. Budyně nad Ohř́ primary school is a small country comprehensive school, which is the equivalent of a Chinese school attended for nine years. There are 220 students and 14 teachers; 15 students with special education needs; and nine grades. Students come from 13 villages, and the furthest villages are 7 kilometres from the school.

\section{Table 1}

The third grade's class schedule in spring semester 2016 of the primary school of Budyně nad Ohři

\begin{tabular}{llllll}
\hline & Mon. & Tue. & Wed. & Thu. & Fri. \\
\hline & Czech & Czech & Czech & Czech & Czech \\
& Mathematics & Mathematics & Mathematics & Mathematics & Mathematics \\
A.M. & English & Czech & English & English & Handcraft \\
& Czech & Liberal study & Handcraft & Liberal study & Music \\
& Drawing & P.E. & Drawing & P.E. & Czech \\
\hline
\end{tabular}

Ref. The website of Budyně nad Ohří: http://www.zs.budyne.cz/index.php?mid=126

The third grade's class schedules of Hekou primary and secondary schools in Yuan san county, Hubei province was selected as the research sample for China. The school is located in Hekou town in the northeast corner of Yuan 'an county, Hubei province. It has 1036 students, 88 faculty and staff, and 9 grades. Most of the students come from Hekou countryside. Students attend the school for a duration of 9 years. 
Table 2

The third grade's class schedule of spring semester 2016 of Hekou primary and secondary schools in Yuan'an county, Hubei province

\begin{tabular}{llllll}
\hline \multicolumn{1}{c}{ Mon. } & Tue. & Wed. & Thu. & Fri. \\
\hline & Chinese & Mathematics & Chinese & Mathematics & Chinese \\
A.M. & Chinese & Local curriculum & Chinese & Chinese & English \\
& Mathematics & Comprehensive course & English & Politics & Local curriculum \\
& Science & Music & Mathematics & P.E. & Local curriculum \\
\hline & Music & Politics & School-based course & Science & P.E.* $^{*}$ \\
P.M. & Art & P.E. & School-based course & Art & ICT* $^{*}$ \\
& Class meeting & Club activity & Club activity & Clean the campus & \\
\hline
\end{tabular}

Ref. The website of Baidu encyclopaedia: https://baike.baidu.com/item/\%E6\%B2\%B3\%E5\%8F\%A3\%E4\%B8\%A D\%E5\%B0\%8F\%E5\%AD\%A6/8931726?fr=aladdin7

*Note: ICT is the abbreviation for information and communication technology. P.E. is the abbreviation for physical education.

The school of Budyně nad Ohři is located in an area which in 2015 had GDP per capita equivalent of $\$ 17251$. According to the average rate estimation this is equivalent to 107000 yuan. In 2015 the Yuan 'an county of Hubei province per capita GDP was 100000 yuan, therefore both areas are roughly the same level of economic development. Both schools are rural schools attended for nine years with the same source of students. Based on this, we can select the two primary schools for a comparative analysis case study, to explore the similarities and differences and develop understanding of basic education in rural schools in China and the Czech Republic.

\section{Results}

\subsection{Comparison of subjects}

According to the FEP BE issued in 2007 in the Czech Republic, the following competencies are regarded as key at the basic/elementary education stage: learning competencies; problem-solving competencies; communication competencies; social and personal competencies; civil competencies; working competencies (Jeřábek, Tupý, et al., 2007). The third-grade curriculum structure arrangement corresponds to the six core skills, including language and language communication courses such as the Czech language; English; mathematics courses; general humanities courses; art and culture courses such as music education, art education, etc.; health courses such as physical education. Practical classes such as labour skills; ICT; citizenship and society; and people and nature are not provided in the third grade in Czech Republic. In table 3, the 2016 third grade 
curriculum from the Spring semester of Budyně nad Ohři primary school is shown. The subjects are Czech, English, Mathematics, P.E., handicrafts, music, drawing, and liberal studies. The curriculum covers language communication, applied mathematics, citizenship and society, arts and culture, health and working which reflects the basic principles and requirements of the FEP BE in the Czech Republic.

According to the experimental plan of compulsory education curriculum issued by the Ministry of Education in 2001, compulsory education in China mainly cultivates students' political, ideological and moral qualities, social civic qualities, scientific and humane qualities, innovative spirit and practical abilities, lifelong learning abilities, physical and mental qualities and aesthetic abilities (Ministry of Education of the People's Republic of China (MoE), 2010). In the third grade, courses such as morality and society, Chinese, mathematics, foreign language, physical education, art, local and school courses and comprehensive practical activities must be offered. In Table 3, the third grade's curriculum in Spring semester 2016 of the primary and secondary school of Hekou are shown as: Chinese, mathematics, English, local curriculum, comprehensive course, politics, science, music, P.E., school-based courses, art, ICT, class meeting, club activity, and labour courses. The curriculum is a good implementation of the national compulsory education curriculum requirements.

Through the above analysis, it is not difficult to find that the number of curriculum subjects in the third grade of a Czech primary school is far less than that in a school in China.

\section{Table 3}

Compare the third grade's schedule of rural primary school in China and Czech Republic

\begin{tabular}{|c|c|c|}
\hline category & the primary school of Budyně nad Ohří & the primary and secondary school of Hekou \\
\hline Curriculum & $\begin{array}{l}8 \text { subjects: Czech, English, Mathematics, P.E., } \\
\text { handicrafts, music, drawing, Liberal study }\end{array}$ & $\begin{array}{l}15 \text { subjects: Chinese, mathematics, English, } \\
\text { local curriculum, comprehensive course, } \\
\text { politics, science, music, P.E., school-based } \\
\text { courses, art, ICT, class meeting, club activity, } \\
\text { labour courses }\end{array}$ \\
\hline Daily schedule & $\begin{array}{l}45 \text { minutes per class, } 10 \text { minutes per break, } \\
5 \text { classes per day }\end{array}$ & $\begin{array}{l}40 \text { minutes per class, } 5-30 \text { minutes per } \\
\text { break, } 6 \text { or } 7 \text { classes per day, } 2 \text { or } 3 \text { classes } \\
\text { in the P.M. }\end{array}$ \\
\hline $\begin{array}{l}\text { Classes per } \\
\text { week }\end{array}$ & 25 & 34 \\
\hline
\end{tabular}

Ref. The website of Budyně nad Ohří: http://www.zs.budyne.cz/index.php?mid=126 https://baike.baidu.com/item/\%E6\%B2\%B3\%E5\%8F\%A3\%E4\%B8\%AD\%E5\%B0\%8F\%E5\%AD\%A6/8931726? $\mathrm{fr}=$ aladdin 


\subsection{Timetable comparison}

\subsubsection{Comparing the school timetable}

From Table 4, we can see each class lasts 45 minutes in Budyně nad Ohří primary school, which is longer than that in the primary and secondary school of Hekou (40 minutes per class). There is a five- or ten-minute break between two classes in the two schools. The difference is in the longer break. The longer break in Budyně nad Ohř́ is 20 minutes, and 30 minutes in Hekou school, which is longer than that of the former. Regarding the learning hours per day, there are 5 classes in the morning. and no classes in the afternoon. In Budyně nad Ohří there are 6 or 7 lessons in one day including 2 or 3 lessons in the afternoon in the primary and secondary school of Hekou. There are 25 classes per week in the school of Budyně nad Ohř́, and 34 classes in the school of Hekou. So, the daily curriculum arrangement of the school of Budyně nad Ohři is relatively compact, students have less time to attend classes, and they have more time for extracurricular independent study, thus the learning burden is relatively light. Czech Republic primary school of this kind of class time arrangement is worth us learning from.

\section{Table 4}

Comparing the third-grade school timetable of a rural primary school in China and in the Czech Republic

\begin{tabular}{lll}
\hline Category & the primary school of Budyně nad Ohří & the primary and secondary school of Hekou \\
\hline Length of each class & $\begin{array}{l}45 \text { minutes per class with } 10 \text { minutes } \\
\text { (short break) or } 20 \text { minutes (long break) }\end{array}$ & $\begin{array}{l}40 \text { minutes per class with } 5 \text { minutes (short } \\
\text { break) or } 30 \text { minutes (long break) }\end{array}$ \\
Classes each day & $\begin{array}{l}5 \text { lessons in the morning and no lesson } \\
\text { in the afternoon }\end{array}$ & $\begin{array}{l}6 \text { or } 7 \text { lessons in one day including } 2 \text { or } 3 \\
\text { lessons }\end{array}$ \\
Classes each week & 25 & 34 \\
\hline
\end{tabular}

Ref. The website of Budyně nad Ohř́: http://www.zs.budyne.cz/index.php?mid=126 https://baike.baidu.com/item/\%E6\%B2\%B3\%E5\%8F\%A3\%E4\%B8\%AD\%E5\%B0\%8F\%E5\%AD\%A6/8931726? $\mathrm{fr}=$ aladdin

\subsubsection{Compare the subjects}

Mastering the native language is the primary task of basic or elementary education in every country in the world. The Czech Republic attaches great importance to the inheritance of its own culture. Czech is also one of the most difficult languages in the world, so learning Czech occupies the most important position in the basic education curriculum of the Czech Republic. From Table 5 it is evident there are 8 Czech classes in a week in the primary school of Budyně nad Ohři which accounts for one third of the 
weekly classes. Chinese classes in the third grade of Hekou school only have 6 classes per week, accounting for $16 \%$ of the total number of class hours per week, which is only half of the proportion of Czech language in the number of class hours per week, and is also lower than the national standard on the proportion of Chinese class hours.

\section{Table 5}

Comparing the third-grade subjects of rural primary school in China and Czech Republic

\begin{tabular}{|c|c|c|c|c|}
\hline \multirow[t]{2}{*}{ Subjects } & \multicolumn{2}{|c|}{$\begin{array}{l}\text { the primary school } \\
\text { of Budyně nad Ohří }\end{array}$} & \multicolumn{2}{|c|}{$\begin{array}{l}\text { the primary and secondary school } \\
\text { of Hekou }\end{array}$} \\
\hline & Classes per week & Proportion & Classes per week & Proportion \\
\hline Chinese & 8 & $32 \%$ & 6 & $16 \%$ \\
\hline Mathematics & 5 & $20 \%$ & 4 & $11 \%$ \\
\hline English & 3 & $12 \%$ & 2 & $6 \%$ \\
\hline P.E. & 2 & $8 \%$ & 3 & $9 \%$ \\
\hline Music & 1 & $4 \%$ & 2 & $6 \%$ \\
\hline Art & 2 & $8 \%$ & 2 & $6 \%$ \\
\hline $\begin{array}{l}\text { Practical courses } \\
\text { (Handicrafts, } \\
\text { Clean the campus) }\end{array}$ & 2 & $8 \%$ & 1 & $3 \%$ \\
\hline Liberal study (Science) & 2 & $8 \%$ & 2 & $6 \%$ \\
\hline Politics & & & 2 & $6 \%$ \\
\hline $\mathrm{ICT}$ & & & 1 & $3 \%$ \\
\hline School-based course & & & 2 & $6 \%$ \\
\hline Local curriculum & & & 3 & $9 \%$ \\
\hline Class meeting & & & 1 & $3 \%$ \\
\hline Club activity & & & 2 & $6 \%$ \\
\hline Comprehensive course & & & 1 & $3 \%$ \\
\hline
\end{tabular}

Ref. The website of Budyně nad Ohří: http://www.zs.budyne.cz/index.php?mid=126 https://baike.baidu.com/item/\%E6\%B2\%B3\%E5\%8F\%A3\%E4\%B8\%AD\%E5\%B0\%8F\%E5\%AD\%A6/8931726? $\mathrm{fr}=$ aladdin

Knowledge-centred courses, such as Czech language, mathematics, foreign language take a proportion of $64 \%$ in a week of learning hours in the school of Budyně nad Ohrí, yet in the Hekou school, the above three courses accounted for only $33 \%$. Children-centred courses, for example, P.E., art, music, accounted for $20 \%$ of the total number of hours per week in the school of Budyně nad Ohři and $21 \%$ in Hekou school. As far as social courses are concerned, practical courses, liberal study, for instance, take a proportion of $16 \%$ in the school of Budyně nad Ohř́, which is far less than the proportion of $49 \%$ in Hekou school. Looking at the course hour's distribution, the school of Budyně nad Ohř focuses more on the knowledge-centred courses, the Hekou school emphasizes social orientation course. Scheduling arrangements for the Czech Republic elementary school mean students have a lot of spare time to participate in 
the community or in afternoon outdoor activities. at school, or in the community many students volunteer for community activities or classes of interest, such as rowing activities, some students choose to study Chinese, the Confucius institute teacher will go to the free classes, so that some of the social courses needed achieve the education goal or show interest in the club activities. Of course, since the Czech Republic attaches great importance to family values, company employees can leave work around 4 P.M. (sometimes at 2 P.M.), so that parents can accompany their children to participate in outdoor sports or other activities in the afternoon, which to some extent supplements the problem of limited class hours.

According to the decision of the CPC central committee and the state council on deepening education reform and comprehensively promoting quality education in 1999, China's basic education is a three-level curriculum system of "national curriculum, local curriculum and school-based curriculum", of which national curriculum accounts for $85 \%$, local curriculum $9 \%$ and school-based curriculum $6 \%$. In Hekou primary and secondary schools, the curriculum schedule for the third grade is arranged according to the three-level curriculum model. Due to the increase of local curriculum and schoolbased curriculum, the corresponding number of class hours of the national curriculum is reduced, and on the other hand, the time of students' free activities and independent study is reduced. At the school of Budyně nad Ohř́, there is no clear identification on the schedule of a local curriculum or a school-based curriculum. The Czech Republic national curriculum is implemented in the schedule using FEP BE regulations across subjects involved in the course of local curriculum and school-based curriculum related content. The school makes arrangements combining the national curriculum with local study. This shows that schools have greater autonomy and flexibility in curriculum setting and arrangement of the Czech Republic. It is not easy to judge which is better or which is worse. However, from the perspective of development trends, compulsory education curriculum in China does need to be reformed. Besides the uniform provision of core curriculum at the national level, local autonomy in curriculum setting and curriculum arrangement should be appropriately delegated to further stimulate creativity and flexibility in basic/elementary education. In particular, there are obvious differences between urban and rural areas and regions in this country. It is difficult for schools in poor villages with lower economy to offer national courses, such as English, ICT, art and sports, as schools are faced with many difficulties to facilitate these such as teachers, conditions and facilities.

It can be seen from the above comparative analysis that the Czech Republic basic education emphasizes subject courses, especially the basic instrumental courses of language, mathematics and foreign languages, which have more organised class hours, this also reflects the problem that the number of class hours in these core basic courses is relatively small in China. The number of learning hours of music, P.E. and art in elementary schools in China and Czech Republic is basically the same. In China, 
moral education courses such as morality and class meetings are greater in number, while Czech Republic primary schools do not have such courses. This shows that China attaches great importance to ideological and political education, which is also a characteristic course of our country's basic education. Generally speaking, Czech Republic primary schools pay more attention to the concentrated learning of subject curriculum, while Chinese primary schools pay more attention to the society-oriented curriculum, with many kinds of courses and no specific emphasis.

\subsection{Comparing the arrangement of the curriculum}

In the curriculum arrangement of the third grade in the primary school of Budyně nad Ohř́, the most difficult language to master is put in the first class in the morning, and the knowledge-centred courses are put in the first three classes in the morning, with alternating arrangements among subjects. The curriculum arrangement is relatively stable every day. As for curriculum arrangement for the third grade in Hekou primary and secondary schools, knowledge-centred courses such as Chinese, mathematics and English are also arranged in the morning every day, which is interlinked with other subjects and arranged alternately every day. On the whole, the arrangement of curriculum of the third grade in the primary school of Budyně nad Ohř́ is reasonable. It embodies the combination of dynamic and static states and of difficulty, fully considering the elementary students' activity characteristics of the cerebral cortex, attention alternating characteristics and factors, for example the change of learning ability is simpler and more convenient for students to remember quickly. The curriculum arrangement of Hekou primary and secondary schools does not give enough consideration to the characteristics of students' attention and physical and mental development. There are many cases of continuous 7 arrangement, and the weekly curriculum structure is complex, which makes it difficult for students to remember quickly. Therefore, there are many improvements to be made.

\subsection{Comparing the daily hours}

Czech Republic primary school students have more flexible time for extracurricular activities, while Chinese primary schools lack flexible time for free activities. As can be seen in table 6 , for the third grade classes at Budyně nad Ohři primary school, school opens at 6:30 in the morning, and students can enter the campus at 7:15 A.M., students need to arrive 15 minutes earlier than the first lesson;7:50 in the morning is the first lesson; 9:30 in the morning is a longer break time of 20 minutes. The students can leave the school after the fifth class at 12:10 in the noon if they do not attend "additional" 
activities in the afternoon. There is not specifically a lunch time, while students can eat lunch in the long break, this can also be in the fifth section after school lunch.

\section{Table 6}

Comparison of the third grade's daily hours of a rural primary school in China and in the Czech Republic

\begin{tabular}{|c|c|c|}
\hline Category & $\begin{array}{l}\text { the primary and secondary } \\
\text { school of Hekou }\end{array}$ & $\begin{array}{l}\text { the primary school } \\
\text { of Budyně nad Ohři }\end{array}$ \\
\hline Get up & 07:00 & \multirow{3}{*}{$\begin{array}{l}\text { The school is open at } 06: 30 \text { in the morning. Pupils enter school } \\
\text { from } 07: 15 \text { to } 07: 35 \text { A.M. The school living area is open from } \\
06: 30 \text { to } 07: 40 \text { in the morning. }\end{array}$} \\
\hline Reading & 07:15-07:45 & \\
\hline Breakfast & $07: 45$ & \\
\hline $1^{\text {st }}$ class & 08:20-09:05 & 07:50-08:30 \\
\hline $2^{\text {nd }}$ class & 09:15-10:00 & 08:40-09:25 \\
\hline Long break & 10:00-10:30 & 09:25-09:45 \\
\hline $3^{\text {rd }}$ class & $10: 30-11: 15$ & 09:45-10:25 \\
\hline $4^{\text {th }}$ class & $11: 25-12: 10$ & $10: 35-11: 20$ \\
\hline Lunch & $12: 10$ & \multirow{3}{*}{$11: 25-12: 10$} \\
\hline Midday rest & $12: 50-01: 45$ & \\
\hline $5^{\text {th }}$ class & $14: 00-14: 45$ & \\
\hline $6^{\text {th }}$ class & $14: 45-15: 40$ & \multirow{3}{*}{$\begin{array}{l}\text { Students go home after 12:10. The school living area is open } \\
\text { from 12:10 to 16:00. Students will be transferred to the school } \\
\text { living area after school at 12:10. There will be a one-and-a-half } \\
\text { hours quiet time in the afternoon and the school gate is closec } \\
\text { during the quiet time. Students can leave school before or } \\
\text { rafter the quiet time. }\end{array}$} \\
\hline Eye exercises & $15: 40-15: 55$ & \\
\hline $7^{\text {th }}$ class & $15: 55-16: 40$ & \\
\hline
\end{tabular}

Ref. The website of Budyně nad Ohří: http://www.zs.budyne.cz/index.php?mid=126

https://baike.baidu.com/item/\%E6\%B2\%B3\%E5\%8F\%A3\%E4\%B8\%AD\%E5\%B0\%8F\%E5\%AD\%A6/8931726? $\mathrm{fr}=$ aladdin

If we count the hours of learning from 7:35 in the morning, the students of the third grade of Budyně nad Ohři primary school study for about 4 or 5 hours every day in school. In contrast, the third-grade students in Hekou School start at 7 A.M. to 4:10 P.M., the school day lasts for 10 hours. Moreover, the course schedule is very full, and they study all day long. It can be seen that Chinese primary school students' study for a long time at school, and basically have no free time and lack of flexibility.

Special attention should be given to the fact that there is a living area in Budyně nad Ohři primary school, a painting studio, handicraft room, reading room, and chess game room, gymnasium, network room and other facilities, provision for ceramics, film and television, art, singing, fishing, dancing, tennis, football, volleyball, oriental dance, yoga, handicrafts, fire-fighting, and the content of activities such as English, organizing students to carry out skiing course or vacation camp activities. In the morning after the required courses prescribed by the state, students can leave home already, but can also learn in the school of living area, according to own choice of after-school pro- 
gramme. They can read a book, draw, watch TV, play games, chat, dance, play musical instruments, preview, sometimes create group shows, take part in outdoor activities and some entertaining games, there even is a small bed for individual students to have a rest. The "living area" of the school is under the care of a special teacher, mainly students' take part in free activities in the activity room, supplemented by teachers' organization. These activities have a nominal fee, parents and students are willing to participate. Most of the courses are sports, such as football, basketball and handball. Sewing or knitting courses are also offered. Knowledge-centred courses may also be offered, such as German, English and so on. The curriculum is directly related to the interests and specialties of the teachers in the school. Because the Czech Republic primary school adopts the package system, in which one teacher is responsible for all the subjects in a class, there will not be too many teachers in the school. The "living area" model of Czech Republic primary schools is similar to the extracurricular activity room of domestic schools in China, which plays an important role in cultivating students' interests, and supporting ability training, promoting communication and cooperation, and is worth learning from for domestic elementary education in China.

\section{Conclusions}

With regards basic education curriculum framework as arranged by the unified regulation from the state, through analysis the primary school of Budyně nad Ohři compared with the Hekou primary and secondary schools, the following Czech Republic elementary education reform practice is worth consideration in China.

\subsection{Reduction of learning anxiety should start in school education by reducing curriculum and class hours.}

Czech Republic primary schools do not have classes in the afternoon, which is the most distinctive difference from Chinese primary schools. The Czech Republic FEP BE also clearly stipulates that the total weekly class hours of the third-grade primary school should be controlled within the range of 22-26 class hours (Jeřábek, Tupý, et al., 2007). The experimental programme of compulsory education curriculum in China stipulates that the total weekly class hours in the third grade should be 30 class hours (MoE of China, 2010). In terms of subjects, there are 8 compulsory courses in the third grade in the Czech Republic and 10 in China. It can be seen that China's compulsory education learning hours and the number of subjects are more than in the Czech Republic. In addition, local education authorities and schools have certain autonomy and flexibility in curriculum setting, and the idea of exam-oriented education has a certain degree of stubborn influence. As a result, the situation of 15 classes and 34 classes per week 
in Hekou primary and secondary schools, for example, leads towards the fact that the learning workload of Chinese primary school students is much heavier than that of Czech Republic. This is only part of the school education, and the family education aspect is more serious. Influenced by the desire for their children's success, many parents in China have signed up for intensive training classes and after school classes for their children to continue their study. This kind of additional practice further aggravates the student's study load, possibly leading the child to be unable to bear learning anxiety. Mandatory curriculum arrangement of more hours is not conducive to the teachers and the growth of students. According to the results of the 2015 PISA (Program for International Student Assessment) (see figure 1), Czech students have lower study anxiety in comparison to the Organization for Economic Co-operation and Development (OECD) member countries (showing a degree of partial light), and the number of Chinese students experiencing anxiety is significantly higher than that of the Czech students, and as compared with the OECD countries (OECD, 2015). It also shows that Czech students' sense of happiness in learning is better than Chinese students' sense of belonging to study, life and school.

\section{Figure 1}

Comparing Czech student well-being with that of Chinese (Ref OECD, 2015)

Life satisfaction

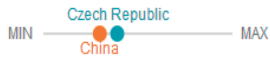

Sense of belonging at school

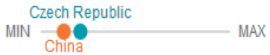

Schoolwork-related anxiety

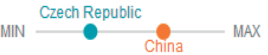

Of course, although in China compulsory education students' learning load is heavier, because of more subjects and class hours, so the overall level of China's basic education is slightly better than the Czech Republic, according to the 2015 PISA. As the PISA shows (see figure 2), China's basic education in science, mathematics and reading is better in all three areas than the Czech Republic, but the level is not a very big difference.

\section{Figure 2}

Comparing Czech student's average performance with that of Chinese (Ref OECD, 2015)

Science

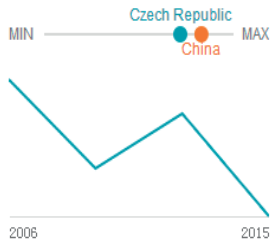

Mathematics

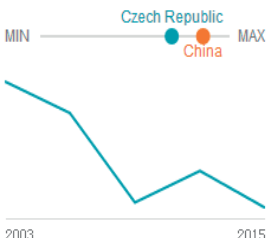

Reading




Compulsory education has many characteristics, such as basic, selective and developing courses. There is no class for students in the afternoon in Czech Republic basic education, which gives us insight. If we really want to reduce a student's learning load, we must further intensify reform of compulsory education curriculum plans, from the curriculum and lessons-these two core elements in school- let the students have more free time each day to explore, to practice, to train their thinking ability, practice ability and innovation ability, to lay a good foundation for follow-up study and for sustainable development.

\subsection{Moral education should pay attention to daily cultivation and acquire in activities.}

There is no specific moral education course in grade three in the Czech Republic, according to the regulation of the Czech Republic FEP BE, cross-curriculum subjects (similar to the Chinese comprehensive course) "personal and social education" has a "moral development" in the content, but the content involves only ethical values, attitudes, practices and so on, and is relatively narrow. Moral education in compulsory education in China should be similar to the cross-curriculum courses in the Czech Republic. Although this cross-curricular subject in the Czech Republic is a mandatory national course, but not all grades must have these courses. It is planned according to the actual situation in the schools, which is given by students' individual learning of cross-curriculum subjects; the organization includes ways to participate, through all kinds of activities to promote the formation of students' good moral character, and not directly as a discipline course in the curriculum. Including skiing in the Winter and Summer camp activities, the Czech primary school develops essential activity projects each year, the school organizes student visits to museums, to wild camping activities, etc., the student is close to nature in the these activities, and abides by the group rules, developing the students' ability in independent life and their basic ability to get along with classmates, promoting the formation of good moral behaviour. As RN Dr. Horáčková, principal of Budyně nad Ohří primary school pointed out in the 2015-2016 annual report, the school creates and actively supports the education about the environmental atmosphere, to influence and shape school work, entertainment, and study the development of everyone's life values and attitudes (Horáčková, 2016). During their stay in Olomouc in the Czech Republic, the writer was deeply impressed by the Czech people's good traffic rule consciousness, environmental protection consciousness, blocks of quiet, considerate care for special needs people, etc. Furthermore, the Czech Republic has very high levels in the human development index. The Czech Republic education assessment from a report by the OECD in 2016 (Shewbridge, C., et al., 2016)) shows 92\% of Czechs from 25 to 64 years old have a senior high school education degree, far above the average of $75 \%$ of the other OECD members. The national quality of life and civilized standards is higher, which 
also reflects that Czech basic education is effective in terms of moral education. On the contrary in the course setting of compulsory education in China, morality is specially offered as a course. In the course of implementation, schools turn their knowledge into knowledge-based courses instead of developmental courses. Students are taught moral knowledge in the classroom instead of leaving the classroom or school. However, they can develop good moral behaviours through observation and experience in nature and society. Some schools even replace moral classes by fundamental courses such as Chinese and mathematics. In this regard, we should learn from the Czech elementary school moral education practices.

\subsection{Ability training should be reformed to use educational resources in schools and improve the convenience of educational services}

Paying attention to the cultivation of students' abilities is a main trend of basic education curriculum reform and education reform in the world, and it is also the focal point of basic education curriculum reform in China. Extracurricular activities play an important role in the cultivation of students' ability. Czech elementary schools offer after-school activities by setting up "living areas" on their campuses for a small fee. The tutoring teachers in the living area are all staff members of the school, which is also an important part of the school. The tutoring content matches the teaching plan of the school and progress is consistent. In China, due to a lot of homework and schools being forbidden to include catch up lessons, parents often send their children to social education and training institutions or learning/counselling institutions to catch up with lessons and strengthen knowledge taught in school, paying a large amount of money. In the Czech school students are free to choose elective courses in the "living area" according to their own interests and hobbies. In a relatively relaxed activity environment, students take the initiative to learn through their internal interests and the sense of responsibility gradually developed in the growth process. This point is better than Chinese students to participating in a variety of extracurricular learning tutorial classes and the generation who dislike it. The "living area" also provides extra care after school for busy parents or dual-income families. From the perspective of cost saving and standardized management, the achievement of educational goals, and the convenience of educational services, the service model of extracurricular activities in the "living area" of the campus in the Czech Republic is worth considering in China. The Czech Republic school provides convenient living areas education service, but in 2017 only 68 students actually signed up to participate in the training of the campus living quarters at Budyně nad Ohři primary school in 2017. The great educator of the Czech Republic, Jan Amos Komenský, has a great influence on the parents of students. He advocated naturalistic education and paid little attention to the pursuit of gradua- 
tion rates. He believed that as long as the personality is sound, along with physical and mental health, then students should learn.

\subsection{To improve quality, autonomy to set the curriculum locally and by school should be actively expanded}

Schools in the Czech Republic enjoy a high degree of autonomy and can develop their educational programmes and other activities to improve professional learning and educational collaboration according to the needs of students and society. One of the major reforms of the Czech Republic FEP BE is to give schools and teachers' greater flexibility and autonomy in implementing national educational goals in local curricula, and teachers have the right to decide which teaching methods and materials to use. From two weeks camping activities each semester in the primary school of Budyně nad Ohř́, we can know the school's autonomy and flexibility of the education plan and curriculum. In fact, from class schedule of the third grade in the primary school of Budyně nad Ohrí, you can see that all national unity required courses on schedule, like local curriculum, school-based curriculum in China is not directly reflected on schedule, but through activities. The primary school of Budyně nad Ohři in 2015-2016 annual report showed that many activities have been carried out in the school between 2015 and 2016 (Horáčková, 2016), such as encyclopaedia knowledge competition, school sports meeting, cultural activities, short trips, ecological action, art competition, sports, and etc., which cover local history, culture, art, environment, sports and so on. These activities are specifically and clearly arranged in the school's annual education plan, which reflects the high flexibility and autonomy of the school's teaching content arrangement. On the contrary, China's basic education schools have the rights in curriculum setting. The state exercises unified control over the curriculum and has made clear and unified provisions on the proportion of class hours and related contents of national curriculum, local curriculum, and school-based curriculum. Schools and local education authorities have little discretion in curriculum setting. This unity of compulsory education curriculum standards is unfit for the current situation of the unbalanced between urban and rural areas in China and is unfavourable to cultivate innovative talents and improve education effectiveness. We should be based on the experience of the Czech Republic, compulsory education curriculum reform plan, to further expand local and school autonomy in the curriculum. 


\subsection{Inclusive education should be implemented to ensure the rights of children with special educational needs.}

Budyně nad Ohří primary school recruited 15 special students, and the school provides them with complete and detailed education plans, including special education needs students in regular classes with other students. To meet special educational the school is equipped with a full-time teacher, barrier-free facilities have been constructed, special education needs children are provided a complete and normal education environment, fully embodying the inclusivity of basic education. According to the Czech Republic education assessment by the OECD in 2016 (Shewbridge, C., et al., 2016), since 2010, the proportion of special education needs students in mainstream schools increases steadily, and presents the development trend of general education and special education integration, at present, $9.2 \%$ of mainstream schools have a special class, special class size of an average of 8.03 people, special education needs students accounted for $6.2 \%$. In 2015, the Czech Republic also issued the Personalized Support for Special Education Law, which was formally implemented in September 2016, to guarantee the rights of students with special education needs to receive support in mainstream education by law. By contrast, there is still a significant gap in China's compulsory education in caring for students with special educational needs and implementing integrated education, and the gap in rural primary schools may be even greater. This is not only due to the lack of professional knowledge, and teachers for special education, but also due to the lack of special education conditions and facilities. What is more, there are some problems such as the deviation of the understanding of the idea of integrated education and the shortage of funds. The care and practice of Czech elementary education for children with special educational needs are worth considering for Chinese elementary education.

\section{Acknowledgements}

This paper was written as part of a specific research of "Research team on the historical development and contemporary reform of rural education in Sichuan Province" by Sichuan high level social science research team. In addition, this paper was funded by the project "Research on the realization path of education informatization in ethnic areas in the 2.0 era of education informatization" (XJR19005).

\section{References}

Glatthorn, A. A., Jailall, J. M. S., \& Jailall, J. K. (2016). The principal as curriculum leader: Shaping what is taught and tested. Thousand Oaks, California: Corwin Press.

Horáčková B. (2016). Výroční zpráva základní školy Budyně nad Ohří, okres Litoměřice za školní rok 2015/2016. [online]. Retrieved from http://www.zs.budyne.cz/index.php?mid=90 
Jeřábek, J. \& Tupý, J. et al. (2007). Framework Educational Programme for Basic Education. Prague: VúP. [online]. Retrieved from http://www.msmt.cz/areas-of-work/basic-education-1?lang=2

Krstić, K.; Stepanović Ilić, I. \& Videnović, M. (2017). Student dropout in primary and secondary education in the Republic of Serbia. Psihološka istraživanja, XX(1): 27-50. DOI: 10.5937/Pslstra1701027K.

Lin, K., Y., et al. (2015). Examining the gaps between teaching and learning in the technology curriculum within Taiwan's 9-year articulated curriculum reform from the perspective of curriculum implementation. International Journal of Technology and Design Education, 25(3): 363-385. DOI: 10.1007/s10798-014-9286-8.

MoE of China. (2001). Compulsory education curriculum experiment plan. [online]. Retrieved from http://old.moe.gov.cn//publicfiles/business/htmlfiles/moe/moe_711/201006/88602.html

MoE of China. (2010). Experimental scheme of compulsory education curriculum setting [DB/OL]. Retrieved from http://old.moe.gov.cn//publicfiles/business/htmlfiles/moe/ moe_711/201006/88602.html.

Ngajie, B. N. \& Ngo, M. M. Ch. (2016). Integration of ICTs into the curriculum of Cameroon primary and secondary schools: A review of current status, barriers and proposed strategies for effective Integration. International Journal of Education and Development using Information and Communication Technology, 12(1): 89-106.

OECD (2013). Education Policy Outlook Snapshot: Czech Republic. [online]. Retrieved from http:// www.oecd.org/education/highlightsczechrepublic.htm.

OECD, (2015). PISA 2015 Key findings for the Czech Republic. [online]. Retrieved from http://www. oecd.org/czech/pisa-2015-czech-republic.htm.

Pingzhong Yide (Jap.), Huang Decheng, et al. (1989). World education dictionary. Changsha, China: Hunan Education Press.

Rowntree, D. (1981). A dictionary of education. London, England: Harper \& Row.

Shewbridge, C., et al. (2016), OECD Reviews of School Resources: Czech Republic 2016. OECD Reviews of School Resources. Paris. France: OECD Publishing. [online]. Retrieved from https://doi. org/10.1787/9789264262379-en.

Zhang Liyong (2008). Schedule and Students' School Life. Shanghai Research on Education, 4.

Zhang Nianhong (1987). Educational Dictionary. Beijing, China: Beijing Press.

Zhu Min (2002). Introduction to Flexible Schedules in American High Schools. Shanghai Research on Education, 2002(6).

ZŠ Budyně nad Ohří. Rozvrh tříd 2019/2020. (Schedule of classes of the primary school 2016/2017). [online]. Retrieved from http://www.zs.budyne.cz/index.php?mid=126.

\section{Contacts:}

Qianjun Tang, Ph.D.

Leshan Normal University, China

Binhe Road 778\#, 614000, Leshan Center District, Sichuan Province, P. R. of China

E-mail:57225351@qq.com

Mgr. Wanbin She

Leshan Normal University, China

Binhe Road 778\#, 614000, Leshan Center District, Sichuan Province, P. R. of China

E-mail: 410435447@qq.com 
Wanbin She is a professor who gained his master's degree from Southwest University. He is a supervisor of Master's degrees in Xihua Normal University and his main research fields are rural education and special education. In addition, he is the director of Sichuan Education Institute Education professional committee, vice chairman of Sichuan Leshan branch James Yen Research Association, vice President of Sichuan University Network Culture Research Association and Sichuan University Teachers' Education Research Association. He has published five monographs and more than 30 articles in Chinese journals. He has led 19 projects from Sichuan Province or the municipal governments and won the Provincial and Municipal Scientific Research Achievement 5. He teaches "fusion education" to postgraduates at Xihua Normal University.

Qianjun Tang, Ph.D. is an associate professor of the Faculty of Education Science at Leshan Normal University. He received his Ph.D. in the study of Education Science in 2018 from the Faculty of Education, Palacky University in Olomouc, Czech Republic. He received a Master's degree in Computing and Technology from Sichuan Normal University in 2006. He works as a teacher of computing in Leshan Normal University. He has published over twenty papers in journals and nearly ten books in different Presses and led over five projects at different levels since he started work in Leshan Normal University. Ph. D. Tang was regarded as a National Excellent Tutor in training college students' teaching skills in 2011, 2012, and 2013; he achieved the Third Place of Teaching Achievement in Leshan Normal University in 2012 and 2013; he achieved the First Place at the 9th and 13th National Multimedia Courseware Competition in 2009 and 2013. 